Gadjah Mada International Journal of Business

September-December 2009, Vol. 11, No. 3, pp. 341-359

\title{
INVESTIGATING THE IMPACTS OF CUSTOMER SATISFACTION ON FIRM PERFORMANCE*
}

\author{
Lianny Leo \\ Faculty of Economics \\ University of Indonesia, Jakarta, Indonesia \\ Lindawati Gani \\ Faculty of Economics \\ University of Indonesia, Jakarta, Indonesia \\ Johnny Jermias \\ Faculty of Business Administration \\ Simon Fraser University, Burnaby, British Columbia, Canada
}

The purpose of this study is to investigate the impact of customer satisfaction on firm performance. We argue that a firm's financial performance will be positively affected by its ability to satisfy its customers. By satisfying its customers, a firm increases its ability to acquire new customers, retain existing customers, and increase customer profitability.

Based on sample of firms listed on the Indonesian Stock Exchange, we hypothesize and find that customer satisfaction is positively and significantly related to firm performance in terms of return on assets and market value of equity. These findings are consistent with the view that customer satisfaction is a leading indicator of financial performance.

Keywords: customer satisfaction; firm performance; non-financial measures

* The data are available from public sources. A list of sample firms is available from the corresponding author upon request. We gratefully acknowledge the valuable comments and suggestions from the participants in the 2008 Asian Academic Accounting Association Conference, Dubai, UAE. 


\section{Introduction}

In the last two decades, researchers and practitioners have shown disappointment with the overemphasis on the use of aggregate financial performance measures. Johnson and Kaplan(1987), for instance, assert that financial performance measures are too aggregate, too late, too distorted, and too focused on past results. These authors suggest that managers should also consider non-financial measures to understand factors that drive performance.

Managers often consider non-financial information more informative because it contains information on the current states of the company's activities and also future consequences of managers' actions (Fisher 1992). Nonfinancial information often assists managers to focus their attention on critical activities or processes involved in managing a firm (Cooper and Kaplan 1991). Furthermore, managers tend to perceive non-financial information as less aggregate, more actionable, and more forward-looking than financial performance measures (Fisher 1992).

One of the most important nonfinancial information is customer satisfaction (Kaplan and Norton 1996). In their seminal paper about balanced scorecard, Kaplan and Norton (2001) contend that satisfied customers will have a positive impact on financial performance because firms that are able to satisfy their customers are more likely to retain their existing customers, increase customer profitability, and acquire new customers. Previous empirical studies investigating the effect of customer satisfaction on performance tend to report a positive result (e.g., Ittner and Larcker 1998; Fornell et al. 2006). Most of these studies, however, have been conducted in developed countries such as the United States and Australia.

Our study is motivated by the fact that despite the importance of customer satisfaction to improving firm performance, few, if any, studies have investigated this phenomenon in a developing country such as Indonesia. Examining the impact of customer satisfaction on performance of companies listed on the Indonesian Stock Exchange is important because unlike in developed countries where customers have access to information related to various products, customers in Indonesia tend to have limited access to information on companies' products or services. Therefore, the research questions that we try to address in this study are: (1) does the customer satisfaction index published annually by SWA magazine affect customer behavior, and in turn, firms' return on assets? and (2) does the customer satisfaction index affect the market value of the firm?

Overall, we find that customer satisfaction is positively related to return on assets. Furthermore, we find that customer satisfaction is also positively related to the firm's market value of equity. Our findings support the balanced scorecard concept in which the accomplishment of the objectives 
in the customer perspective leads to improved financial results. The results, however, indicate that customer satisfaction does not have a significant effect on cumulative excess returns and market-to-book ratio.

The remainder of this paper is organized as follows. Section two discusses previous related literature, hypotheses, and regression models used to test the predictions. Section three explains the research method and how to measure the variables used in this study. Section four presents the results of the statistical analysis followed by general discussion on the main results, recommendations, and directions for future research in this area.

\section{Related Literature and Hypotheses}

Accounting information has long been criticized for providing managers with information that is too late, too aggregate, and too distorted to be relevant in today's business environment characterized by rapidly changing environment (Simons 1990; Johnson and Kaplan 1987). It is not surprising, therefore, that in recent years, researchers and practitioners have shown a growing interest in using non-financial information in monitoring and decision-making processes. Researchers are particularly interested in investigating whether non-financial information affects financial performance. One of the non-financial information that has attracted much atten- tion in the accounting literature is customer satisfaction.

This study uses the balanced scorecard (Kaplan and Norton 1996, 2001, and 2006) as the underlying theory to develop the hypotheses. We focus on two perspectives in the balanced scorecard: (1) customer and (2) financial perspectives. Customer satisfaction is the main objective in the customer perspective since firms that do well in satisfying their customers will increase their likelihood to improve their financial performance.

Previous studies examining the relationship between customer satisfaction and performance tend to report positive results. Fornell et al. (1996), for example, investigated the effects of the public release of customer satisfaction index on firms' stock market returns. They find that the disclosure of non-financial customer satisfaction measures provides new and forwardlooking information, not completely reflected by traditional accounting performance measures such as profit, for the stock market. In a similar vein, Ittner and Larcker (1998) examined whether customer satisfaction index served as a leading indicator of financial performance. They report that customer satisfaction positively and significantly affects firm value although the market does not instantaneously react to the publication of the customer satisfaction index. Rather, the market reacts to the customer index publication ten days after the publication date. 
Gadjah Mada International Journal of Business, September-December 2009, Vol. 11, No. 3

Kaplan and Norton (1996) assert that customer perspective consists of market share, customer retention, customer acquisition, customer satisfaction, and customer profitability. They argue, however, that customer satisfaction is the most important measure as this measure is the prerequisite of the other measures. This is because satisfied customers will enable the firm to acquire new customers, retain existing customers, increase customer profitability, and, in turn, increase market share. Figure 1 shows how customer satisfaction affects financial performance (Kaplan and Norton 1996).

Figure 1 shows that customer satisfaction will eventually increase a firm's market share through the acqui- sition and retention of customers. Increased market share leads to increased sales revenues. Other things equal, increased sales revenues will improve the firm's profitability such as return on assets (ROA). Return on assets represents accounting performance related to how management uses the firm's assets efficiently and effectively. Some studies have shown that managers prefer return on assets to measure their performance since ROA is more controllable than market-based measures which tend to be influenced by exogenous economic factors (Verrecchia 1986; Elitzur and Yaari 1995). Similarly, Hutchinson and Gul (2003) argue that ROA is considered an appropriate proxy for performance

Figure 1. Customer Satisfaction as A Leading Indicator of Financial Performance
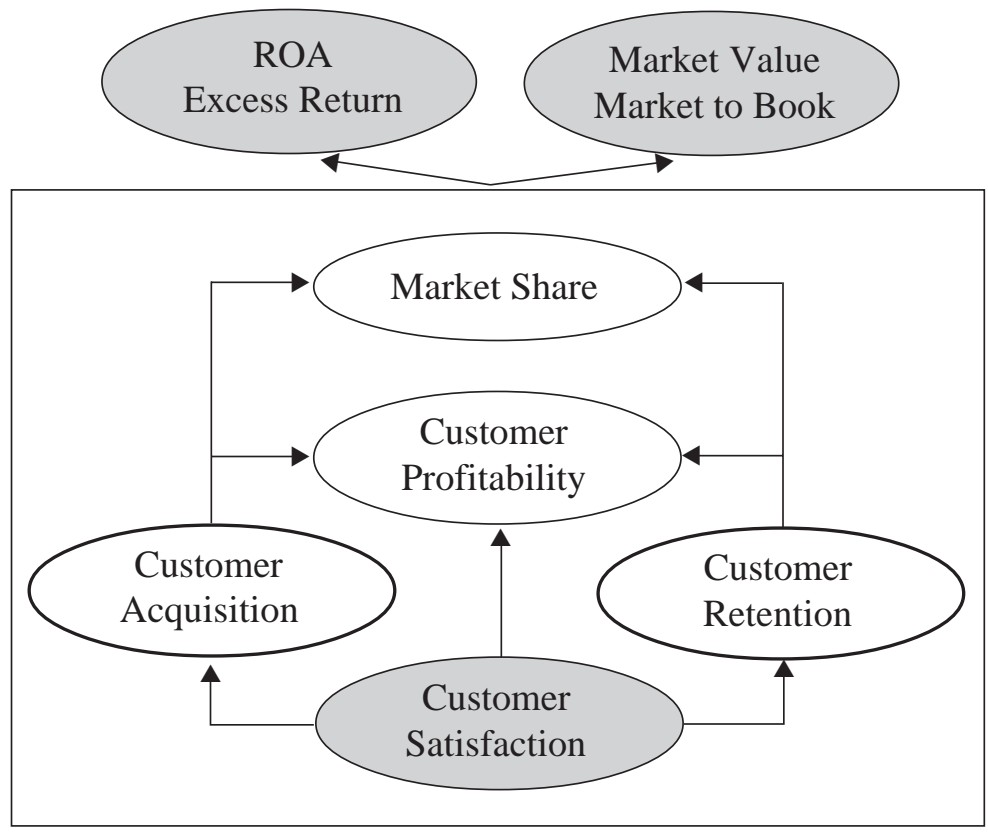

Financial Performance

Customer Perspective 


\section{Leo et al.-The Impact of Government Debt Issuance on Short-Term Interest Rates in indonesia}

since this measure tends to be more controllable by managers. Furthermore, Vining and Broadman (1992) report that ROA is one of the most commonly used indicators of profitability that have been used in the literature. ROA has also been shown in the accounting and management literature to be positively and significantly correlated with other measures of performance such as Tobin's Q, return on equity, and return on sales (e.g., Jermias 2007; Vining and Broadman 1992; Parker and Hartley 1991). Hence, the following hypothesis is tested:

H1: Customer satisfaction will have a positive impact on firms' return on assets.

In addition, this study uses market-based performance measures to test the robustness of the results to using different measures of performance. While accounting-based performance measures such as return on assets tend to be under the control of managers, Merchant and van der Stede (2007) argue that managers can manipulate ROA more easily than market-based measures. To address this problem, we also use three market-based performance measures: (1) market-to-book ratio, (2) market value of equity, and (3) cumulative excess returns.

Furthermore, Srivastava et al. (1998) propose that there are four reasons as to why customer satisfaction will affect a firm's stock return and market value. First, satisfied customers basically mean that the firm needs less effort and resources to persuade the customers to buy the firm's products or services. Second, satisfied customers will pay their liabilities on time. Third, satisfied customers reduce the need for incurring sales and marketing expenses. Finally, satisfied customers decline the cash flow variability, leading to decreased cash flow risks. In a similar vein, Anderson and Mansi (2009) contend that customer satisfaction should influence performance positively through its positive effects on customer behavior that determine the stability of future profits due to greater customer retention, bigger repeated purchases, positive recommendations, and reduced costs of complaints.

Empirical studies have consistently reported that customer satisfaction affects performance positively (e.g., Chand 2010; Tuli and Bharadwaj 2009; Anderson and Mansi 2009). Based on a questionnaire survey of Indian-based hotels, Chand (2010) reports that customer satisfaction is positively and significantly related to performance. Tuli and Bharadwaj (2009) use a panel data sample of publicly traded U.S. firms and satisfaction data from the American Customer Satisfaction Index to investigate the impacts of customer satisfaction on various measures of performance. The results of their study indicate that investment in customer satisfaction has a positive impact on firm performance. In a similar vein, Anderson and Mansi (2009) report that firms with lower customer satisfaction exhibit lower credit ratings and higher cost of debts. 
In summary, satisfied customers increase cash flows and decrease the cash flow risks which make the firm's stock more attractive to investors. Hence, the following hypotheses are examined:

H2: Customer satisfaction will have a positive impact on firm's marketto-book ratio.

H3: Customer satisfaction will have a positive impact on firms' market value.

H4: Customer satisfaction will generate excess returns to investors.

To test the first hypothesis, we use the following regression model:

$$
\begin{aligned}
\mathrm{ROA}_{\mathrm{i}, \mathrm{t}+1}= & \beta_{0}+\beta_{1} \mathrm{ROA}_{\mathrm{i}, \mathrm{t}}+ \\
& \beta_{2} \mathrm{CSI}_{\mathrm{i}, \mathrm{t}}+\varepsilon_{\mathrm{i}}
\end{aligned}
$$

where $R O A_{i, t}$ is the performance of firm $i$ in year $t$ measured as net income divided by total assets based on current annually audited financial statements, CSI $_{i, t}$ is the customer satisfaction index of firm $i$ in year $t$, and $R O A_{i, t+1}$ is the return on assets of firm $i$ in the following year.

To test the second hypothesis, we use the following regression model:

$$
\begin{aligned}
\operatorname{MTB}_{\mathrm{i}, \mathrm{t}+1}= & \beta_{0}+\beta_{1} \mathrm{MTB}_{\mathrm{i}, \mathrm{t}}+ \\
& \beta_{2} \operatorname{CSI}_{\mathrm{i}, \mathrm{t}}+\varepsilon_{\mathrm{i}}
\end{aligned}
$$

where $M T B_{i, t}$ is the performance of firm $i$ in year $t$ measured as market value of the firm's outstanding shares divided by book value of total assets based on current annually audited fi- nancial statements, and $M T B_{i, t+1}$ is the market-to-book ratio of firm $i$ in the following year.

To test the third hypothesis, we use the following regression model:

$$
\begin{aligned}
\operatorname{lnMVE} E_{\mathrm{i}, t+1}= & \beta_{0}+\beta_{1} \operatorname{lnASSETS} \operatorname{sit}_{\mathrm{i}+1} \\
& +\beta_{2} \operatorname{lnLIAB} \mathrm{i}_{\mathrm{i}, \mathrm{t}+1}+ \\
& \beta_{3} \operatorname{lnCSI} \mathrm{in}_{\mathrm{i}, \mathrm{t}} \varepsilon_{\mathrm{i}}
\end{aligned}
$$

where $\ln M V E_{i, t+1}$ is the natural logarithm of market capitalization on the audited position of firm-year $i$ in the following year, $\ln$ ASSETS $_{i, t+1}$ is the natural logarithm of annually audited book value of total assets of firm-year $i$ in the following year, $\ln L I A B_{i, t+1}$ is natural logarithm of annually audited book value of total liabilities of firm $i$ in the following year, and $\operatorname{lnCSI} i$ is the natural logarithm of customer satisfaction index of firm $i$ in current year.

To test the fourth hypothesis, we use the following regression model:

$\mathrm{CER}_{\mathrm{i}}=\beta_{0}+\beta_{1} \mathrm{UE}_{\mathrm{i}}+\beta_{2} \mathrm{CSI}_{\mathrm{i}}+\varepsilon_{\mathrm{i}}$

where $C E R_{i}$ is the current performance of firm $i$ measured as the cumulative excess returns on the firm's shares for the period of five, 10, and 15 days since the publication of the customer satisfaction index by SWA magazine, $U E_{i}$ is the unexpected earnings of firm $i$ measured as the difference of pre-tax ordinary current year income from prior year income scaled by prior year income, and $\mathrm{CSI}_{i}$ is the current customer satisfaction index of firm $i$. 


\section{Research Method}

\section{Sample Selection}

The sample consists of firms listed on the Indonesian Stock Exchange (IDX) for six consecutive years (20032008). Financial information is obtained from the OSIRIS database. Only firms with complete information on net income, total assets, total liabilities, total shareholders equity, number of outstanding shares, and share price for the six years are included in the sample. Firms with negative balance of net assets and firms that are surviving entities in merger transactions are excluded from the sample as negative balances are not transformable into logarithmic function and the measurement of unexpected earnings does not suit the accounting performance of surviving entities due to synergy effect. Information regarding the customer satisfaction index is obtained from SWA magazine published annually for the period of 2003-2008.

The reason we select this particular period is because beginning in 2003, the magazine has changed its scoring systems to determine the customer satisfaction index. The customer satisfaction index is calculated based on a uniform Likert scales of 1-5 on product characteristics in terms of satisfaction towards quality, satisfaction towards value, whether the product is perceived as the best in its category, and the ability of the product to meet future expectation(SWA 19/XIX September 18-October 1, 2003 edition, pages 26-36). Prior to 2003, the index was calculated using multivariate analysis based on customers' responses to questions related to satisfaction towards quality and satisfaction towards value using Likert scales of 1-5, and whether the product is perceived as the best in its category (a dummy variable of 1 for a positive answer and 0 otherwise) (SWA 18/XVI, September 7-20, 2000 edition, pages 26-35).

The numbers of respondents surveyed by the magazine were 10,200 for 2003 to 2004, and 10,500 for 2005 to 2008. Nine thousand respondents were randomly selected, and the remaining were considered booster respondents from high income cluster. The surveys were conducted in six big cities in Indonesia: Jakarta, Bandung, Semarang, Surabaya, Medan, and Makassar. Respondents were selected based on the following criteria: (1) age between 15-65 years old, (2) monthly income between US\$80 and US\$400 (Rp750,000 to Rp3,500,000), (3) equal number of male/female respondents, and (4) for the high income respondents, their monthly income should be more than US\$400. The sampleis based on multi-stage random sampling for each income category. In addition, faceto-face interviews were conducted using structured questionnaires.

We then matched the customer satisfaction score of a product with the public company that produced the product. If a company has more than one product being surveyed, we use the product with the highest satisfaction score. The final sample consists of 199 
Gadjah Mada International Journal of Business, September-December 2009, Vol. 11, No. 3

Table 1. Sample Selection

\begin{tabular}{lccc}
\hline Year & $\begin{array}{c}\text { Number of } \\
\text { Products Surveyed }\end{array}$ & $\begin{array}{c}\text { Number of } \\
\text { Product Categories }\end{array}$ & $\begin{array}{c}\text { Number of } \\
\text { Matched Public } \\
\text { Companies*) }\end{array}$ \\
\cline { 2 - 2 } 2003 & 363 & 64 & 26 \\
2004 & 522 & 69 & 33 \\
2005 & 543 & 70 & 36 \\
2006 & 670 & 87 & 39 \\
2007 & 646 & 92 & 43 \\
2008 & 687 & 100 & 38 \\
Total number of matched public companies & & 215 \\
Financial positions with negative balance of net assets or & 12 \\
surviving entities & & 4 \\
Incomplete stock price data & & 199 \\
Number of sample &
\end{tabular}

Source: Summarized from SWA magazines

*) obtained from matching procedures of products to the producers that are public companies

firm-year observations. Table 1 summarizes the sample selection.

\section{Variables Measurement}

\section{Independent Variable}

The independent variable used in this study is the customer satisfaction index (CSI). CSI is measured based on the structural model proposed by Fornell et al. (1996). Figure 2 shows the structural model proposed by Fornel et al. (1996).

CSI is determined by customer expectation, perceived quality, and perceived value. According to this model, customer satisfaction will lead to customer loyalty or customer complaint. In the United States, the mea- surement of CSI began in 1994. Customer satisfaction for each product for a firm is calculated based on the weighted-average of all products produced by the firm (Hansen and HennigTurau 1999). The survey is conducted every quarter using 18 structured questions, and responses are given in a 1-10 Likert scale. The customer satisfaction index for each firm ranges from zero to 100 (Morgeson 2005).

In Indonesia, customer satisfaction is defined as a condition in which customers perceive that a product meets their needs and expectations (SWA magazine, September 3-12, 2007 Edition). SWA magazine, an Indonesian bi-weekly magazine, collaborates with Frontier Consulting Group to conduct 
Figure 2. Structural Model of Customer Satisfaction Index

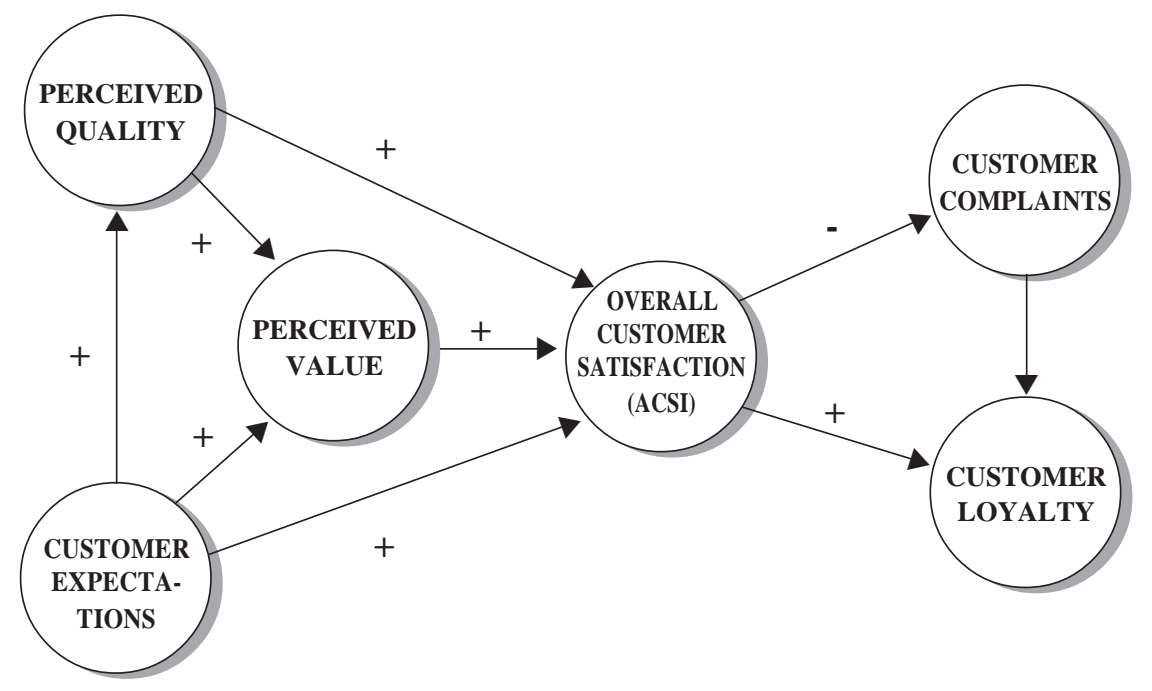

Source: (Fornell, et al. 1996)

Figure 3. Determination of Customer Satisfaction Index in Indonesia

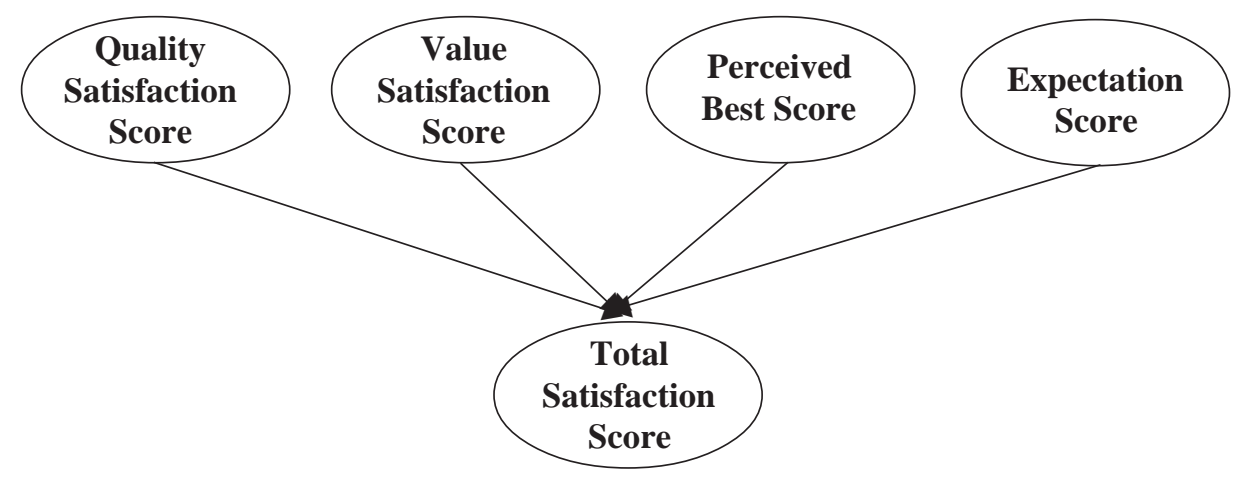

annual surveys to determine the customer satisfaction index for various products sold in Indonesia. Similar to the structural model proposed by Fornell et al. (1996), the customer satisfaction index is based on customer perception in terms of quality, value, rank, and expectation. Figure 3 shows how to determine the customer satisfaction index.

The quality satisfaction score measures customer satisfaction with respect to product/service quality. The value satisfaction score measures customer satisfaction in terms of prices relative to the quality of the product. 
Gadjah Mada International Journal of Business, September-December 2009, Vol. 11, No. 3

Subsequently, the perceived best score measures customer perception on the rank of the product relative to competitors' products. Meanwhile, the expectation score measures the ability of the product to satisfy customers' future expectations. The total satisfaction index is calculated based on the weighted-average of the customers' responses to the questions related to quality, value, rank, and expectation in a Likert scale of 1 to 5 .

In this study, the customer satisfaction index (CSI) is measured based on the index reported annually in SWA magazine. Higher index indicates more satisfaction.

\section{Dependent Variables}

There are four dependent variables used in this study: (1) return on assets (ROA); (2) market-to-book ra- tio (MTB); (3) market value of equity (MVE); and (4) cumulative excess returns (CER). ROA is measured as the ratio of net income to total assets. MVE is measured based on the number of outstanding shares multiplied by the price per share. Market-to- book ratio is the market value of the shares divided by the book value of assets. Following the approach used by Teoh and Wong (1993), we calculate CER as the sum of the excess returns (based on the market-adjusted return) for the period of five, 10, and 15 days since the publication of the customer satisfaction index by SWA magazine. The determination of window period to calculate the cumulative excess returns for each year is presented in Table 2. We use data from audited financial statements as of December 31 since it is the closest date to the

Table 2. Determination of Window Period for Calculating the Cumulative Excess Returns

\begin{tabular}{|c|c|c|c|c|}
\hline Year & $\begin{array}{c}\text { Publication } \\
\text { date of SWA } \\
\text { magazine }\end{array}$ & 5-day Period & 10-day Period & 15-day Period \\
\hline 2003 & Sep 18 - Oct 1 & Sep $18-25$ & Sep 18 - Oct 2 & Sep 18 - Oct 9 \\
\hline 2004 & Sep 30 - Oct 13 & Sep 30 - Oct 6 & Sep 30 - Oct 13 & Sep 30 - Oct 20 \\
\hline 2005 & Sep $15-28$ & Sep 15 - 21 & Sep $15-28$ & Sep 15 - Oct 5 \\
\hline 2006 & Sep 21 - Oct 4 & Sep 21 - Sep 27 & Sep 21 - Oct 4 & Sep 21 - Oct 11 \\
\hline 2007 & Sep $3-12$ & Sep $3-7$ & Sep $3-14$ & Sep 3 - 21 \\
\hline 2008 & Sep 18 - Oct 8 & Sep 18 - 24 & Sep 18 - Oct 7 & Sep 18 - Oct 16 \\
\hline
\end{tabular}


Leo et al.-The Impact of Government Debt Issuance on Short-Term Interest Rates in indonesia

event where the customer satisfaction index is published.

\section{Control Variables}

Previous studies have shown that firm size and leverage affect firm performance (e.g., Frank and Goyal 2003; Ramaswamy 2001). To control for the potential effects of these variables on the dependent variables, in regression model 3 we use logarithmic function of the book value of a firm's total assets to measure firm size and the book value of a firm's total liabilities to measure firm leverage.

Accounting unexpected earnings affect market excess returns (e.g., Ball and Brown 1968; Beaver et al. 1997). In regression model 4 , unexpected earnings are measured as the difference between pre-tax ordinary current year income and prior year income scaled by prior year income.

\section{Data Analysis and Results}

Panel A of Table 3 presents the descriptive statistics of the variables used in this study. The average ROA is 9.04 percent. The average logarithmic function of the firms' market values is 21.81. The means of excess returns are -1.7 percent, -0.01 percent, and -0.1 percent for the five-, 10-, and 15-day windows, respectively. The average customer satisfaction index is 4.01. With respect to the control variables, the averages of logarithmic function of total assets and total liabilities are 22.27 and 21.52, respectively, and the average unexpected earnings is 0.48 .
Panel B of Table 3 shows the Pearson's correlations among variables used in this study. The positive and significant correlations between ROA and MTB $(r=0.59, p<0.01)$, ROA and MVE $(r=0.14, p<0.05)$, and MTB and MVE $(r=0.39, p<0.01)$ indicate that the three performance indicators used in this study measure the same construct. The positive and significant correlations between CSI and ROA ( $\mathrm{r}$ $=0.32, \mathrm{p}<0.01)$, MTB $(\mathrm{r}=0.43, \mathrm{p}<$ $0.01)$, and MVE $(r=0.46, p<0.01)$ provide early supports to the hypotheses stated in the previous section.

Table 4 presents the results of the regression analyses for the return on assets (ROA) and market-to-book ratio (MTB) as the dependent variables. The F-statistics for the regressions are significant for ROA $\left(\mathrm{F}=77.36, \mathrm{R}^{2}=\right.$ $0.44)$ and $\operatorname{MTB}\left(\mathrm{F}=430.58, \mathrm{R}^{2}=\right.$ 0.81). Hypothesis H1 predicts that customer satisfaction will affect ROA positively. This hypothesis is examined with the estimated coefficient on CSI. The positive and significant coefficient on CSI $(\beta=0.08, \mathrm{p}<0.01)$ confirms the hypothesis that customer satisfaction has a positive impact on performance in terms of ROA.

Hypothesis H2 expects that customer satisfaction will have a positive impact on firms' market-to-book ratio. This hypothesis is tested with the estimated coefficient on CSI. The result indicates that the coefficient on CSI is not statistically significant. Hence, the finding does not confirm hypothesis H2. 
Gadjah Mada International Journal of Business, September-December 2009, Vol. 11, No. 3

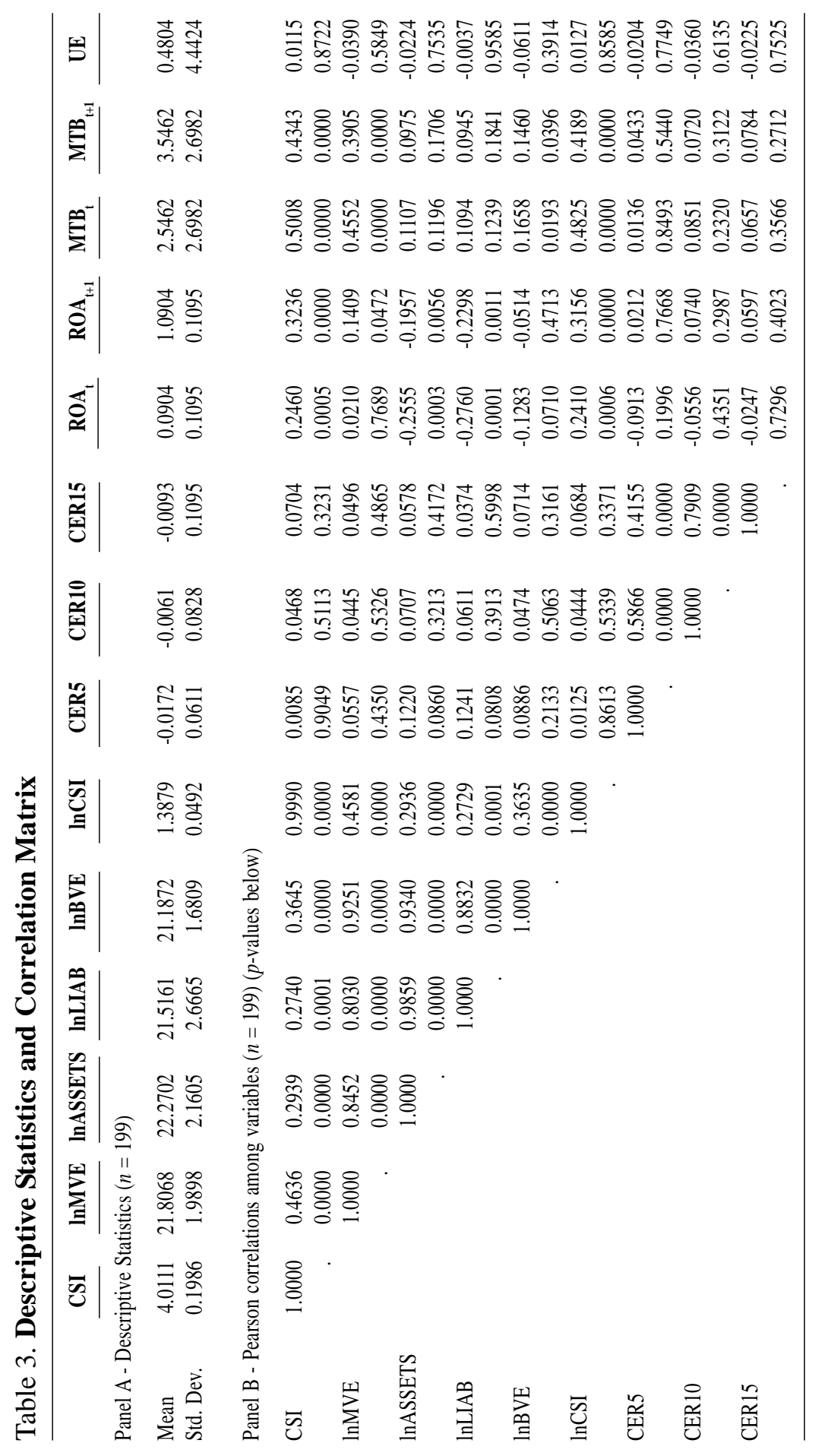




\section{Leo et al.-The Impact of Government Debt Issuance on Short-Term Interest Rates in indonesia}

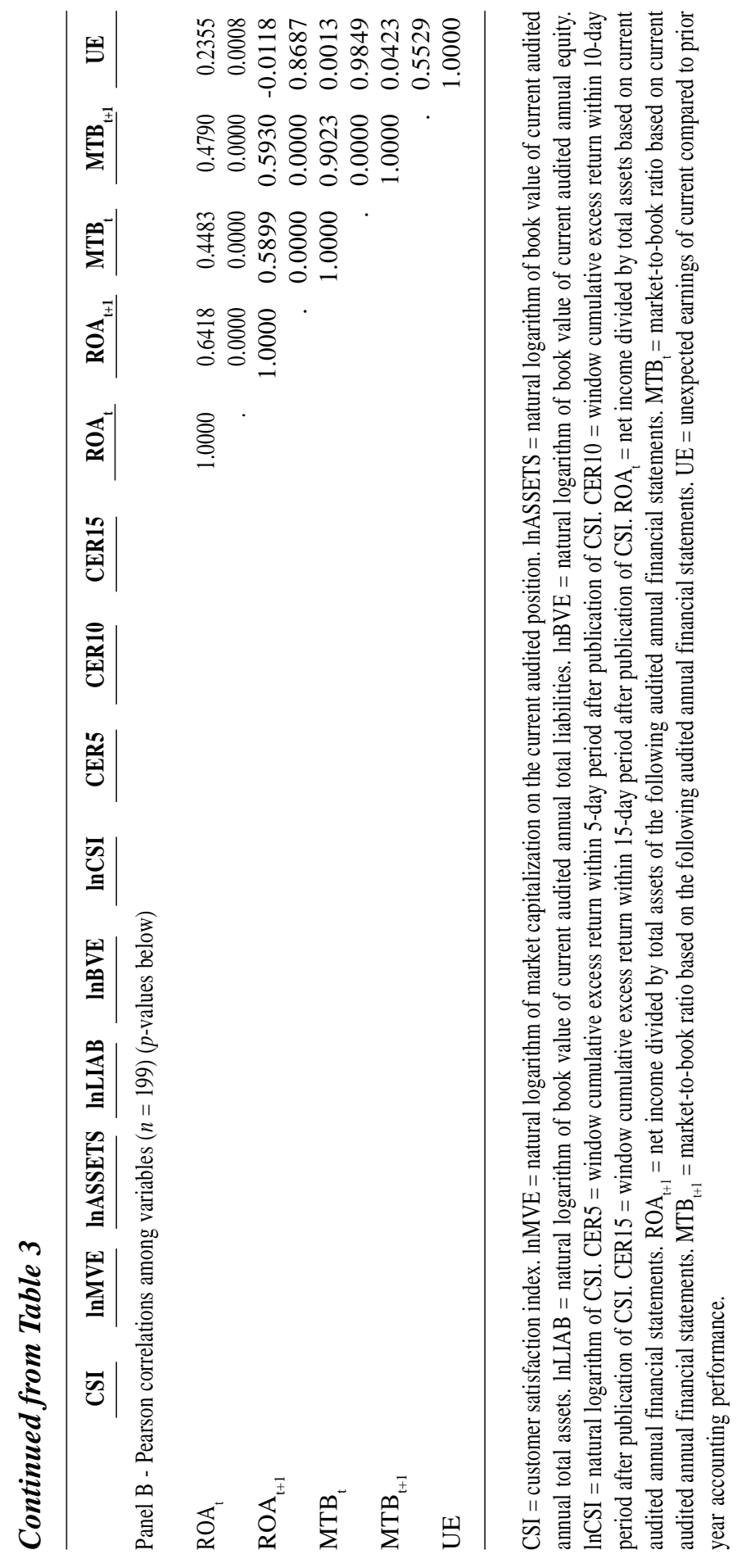


Gadjah Mada International Journal of Business, September-December 2009, Vol. 11, No. 3

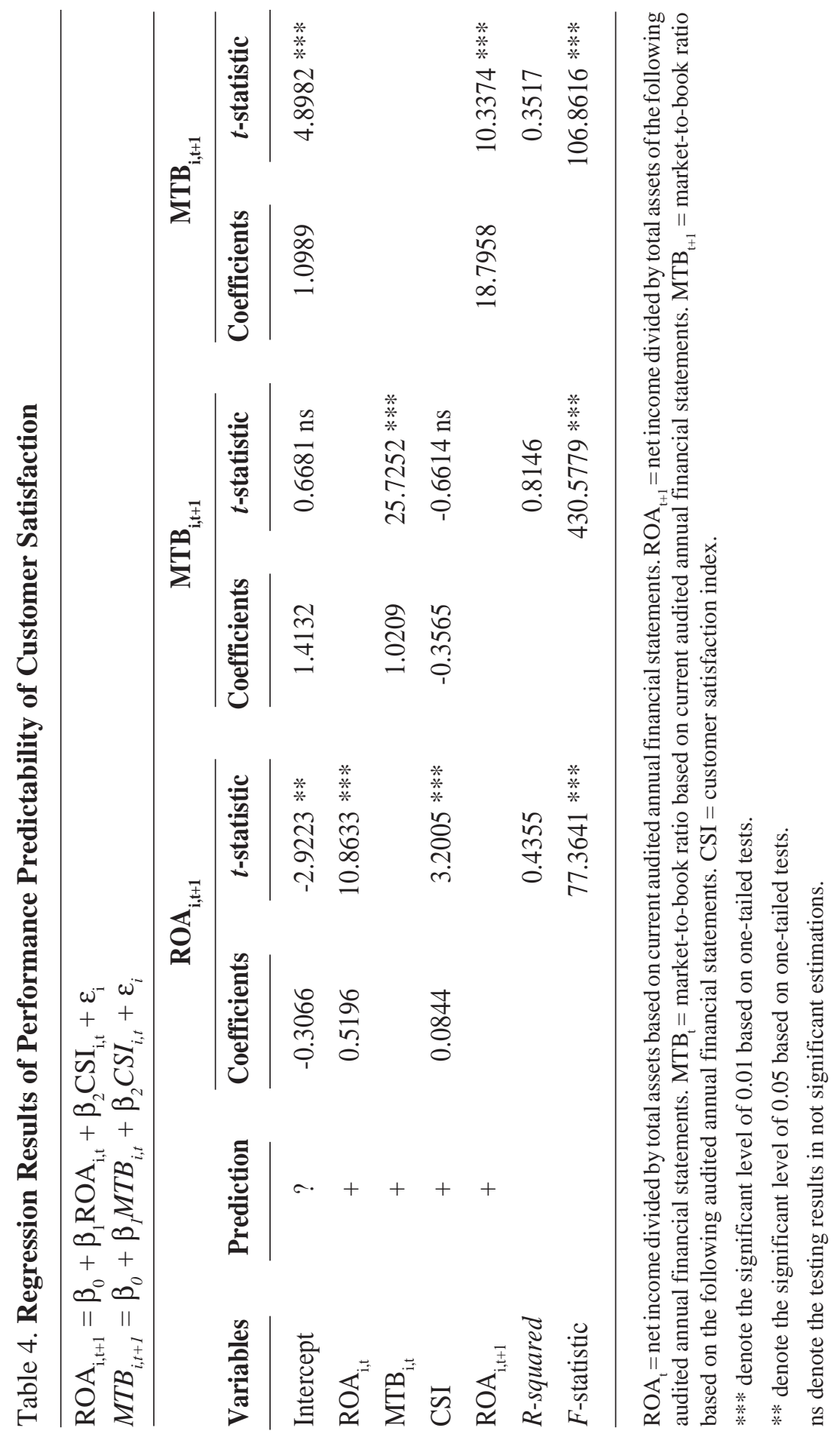


Leo et al.-The Impact of Government Debt Issuance on Short-Term Interest Rates in indonesia

Table 5. Regression Results of Value Relevance of Customer Satisfaction

\begin{tabular}{|c|c|c|c|c|c|}
\hline \multirow[b]{2}{*}{ Variables } & \multirow[b]{2}{*}{ Prediction } & \multicolumn{2}{|c|}{ Regression (1) } & \multicolumn{2}{|c|}{ Regression (2) } \\
\hline & & Coefficients & t-statistic & Coefficients & t-statistic \\
\hline Intercept & ? & -10.1715 & $-5.1710 * * *$ & -7.9993 & $-5.5683 * * *$ \\
\hline lnASSETS & + & 1.5915 & $8.6556 * * *$ & & \\
\hline $\operatorname{lnLIAB}$ & - & -0.7154 & $-4.8327 * * *$ & & \\
\hline $\operatorname{lnBVE}$ & + & & & 1.0347 & $31.9748 * * *$ \\
\hline $\operatorname{lnCSI}$ & + & 8.5940 & $6.1249 * * *$ & 5.6804 & $5.1358 * * *$ \\
\hline$R$-squared & & & 0.7880 & & 0.8729 \\
\hline F-statistic & & & $241.6104 * * *$ & & $672.9988 * * *$ \\
\hline
\end{tabular}

lnMVE = natural logarithm of market capitalization on the current audited position. InASSETS = natural logarithm of book value of current audited annual total assets. $\operatorname{lnLIAB}=$ natural logarithm of book value of current audited annual total liabilities. $\operatorname{lnBVE}=$ natural logarithm of book value of current audited annual equity. InCSI = natural logarithm of CSI (customer satisfaction index).

*** denote the significant level of 0.01 based on one-tailed tests.

Further test is done by regressing ROA on MTB. The result confirms that firm accounting performance as measured by ROA affects firm market performance measured by MTB, suggesting that customer satisfaction has an indirect positive impact on performance in terms of MTB via ROA.

Table 5 presents the results of the regression analysis for future market value of equity (MVE) as the dependent variable. The F-statistics for the regression is significant $(\mathrm{F}=241.61$, $\mathrm{R}^{2}=0.79$ ). Hypothesis H3 predicts that customer satisfaction index will have a positive impact on firms' future market value of shares. Hypothesis H3 is tested with the estimated coefficient on CSI. The positive and significant coefficient on CSI $(\beta=8.59, \mathrm{p}<0.01)$ supports the hypothesis that customer satisfaction has a positive impact on performance in terms of firms' future market value.

Table 6 presents the results of the regression analysis for cumulative excess returns (CER) as the dependent variable. The F-statistics for the regressions is not significant $(\mathrm{F}=0.05$, $\left.\mathrm{R}^{2}=0.0005\right)$. Hypothesis $\mathrm{H} 4$ predicts that customer satisfaction index will generate cumulative excess returns to shareholders. Hypothesis H4 is examined with the estimated coefficient on CSI. The result shows that although the pattern of relationship is found as predicted, the coefficient on CSI is not statistically significant. Hence, the result does not substantiate hypothesis H4. 
Gadjah Mada International Journal of Business, September-December 2009, Vol. 11, No. 3

Table 6. Regression Results of Market Response to Customer Satisfaction in Five-, Ten-, and Fifteen-Day Period After Publication

$C E R_{i}=\beta_{0}+\beta_{1} U E_{i}+\beta_{2} C S I_{i}+\varepsilon_{i}$

\begin{tabular}{|c|c|c|c|c|c|c|c|}
\hline \multirow[b]{2}{*}{ Variables } & \multirow[b]{2}{*}{$\begin{array}{c}\text { Pre- } \\
\text { diction }\end{array}$} & \multicolumn{2}{|c|}{ Five-day period } & \multicolumn{2}{|c|}{ Ten-day period } & \multicolumn{2}{|c|}{ Fifteen-day period } \\
\hline & & Coefficients & $\begin{array}{c}t- \\
\text { statistic }\end{array}$ & Coefficients & $\begin{array}{c}t- \\
\text { statistic }\end{array}$ & Coefficients & $\begin{array}{c}t^{-} \\
\text {statistic }\end{array}$ \\
\hline Intercept & ? & -0.0279 & $-0.3160 \mathrm{~ns}$ & -0.0847 & $-0.7098 \mathrm{~ns}$ & -0.1652 & $-1.0481 \mathrm{~ns}$ \\
\hline $\mathrm{UE}_{\mathrm{i}}$ & + & -0.0003 & $-0.2870 \mathrm{~ns}$ & -0.0007 & $-0.5127 \mathrm{~ns}$ & -0.0006 & $-0.3272 \mathrm{~ns}$ \\
\hline $\begin{array}{l}\text { CSI } \\
\text { R-squared }\end{array}$ & + & 0.0027 & $\begin{array}{l}0.1226 \text { ns } \\
0.0005\end{array}$ & 0.0197 & $\begin{array}{l}0.6626 \text { ns } \\
0.0035\end{array}$ & 0.0389 & $\begin{array}{l}0.9920 \mathrm{~ns} \\
0.0055\end{array}$ \\
\hline F-statistic & & & $0.0483 \mathrm{~ns}$ & & $0.3471 \mathrm{~ns}$ & & $0.5419 \mathrm{~ns}$ \\
\hline
\end{tabular}

CER5 = window cumulative excess return within 5-day period after publication of CSI. CER10 = window cumulative excess return within 10-day period after publication of CSI. CER15 = window cumulative excess return within 15-day period after publication of CSI. UE = unexpected earnings of current compared to prior accounting performance. CSI = customer satisfaction index.

ns denote the testing results in not significant estimations.

\section{Discussion and Conclusions}

This paper investigates the impacts of customer satisfaction on various measures of firm performance. We use customer satisfaction index published by SWA magazine as the proxy for customer satisfaction of a firm's products. Consistent with our predictions, the results of this study indicate that customer satisfaction positively affects firms' profitability in terms of return on assets and market value of shares. These results are consistent with those of Ittner and Larcker (1998) and Fornell et al. (2006). However, the results do not support the hypotheses concerning the impacts of customer satisfaction on market-tobook ratio and cumulative excess re- turns. With respect to the cumulative excess returns, the result suggests that investors do not respond to the publication of customer satisfaction index by SWA magazine, at least for the period up to 15 days after the release of the information. There are two plausible reasons for this result. First, investors in Indonesia might not consider customer satisfaction index published by SWA magazine as an important variable in driving firm performance. As such, their investment decisions on whether to buy, sell, or hold the company's shares are not influenced by this index, resulting in insignificant relationships between customer satisfaction index and both market-to-book ratio and cumulative excess returns. Second, the market-based 


\section{Leo et al.-The Impact of Government Debt Issuance on Short-Term Interest Rates in indonesia}

measures might be significantly influenced by other exogenous economic factors (Verrecchia 1986; Elitzur and Yaari 1995; Hutchinson and Gul 2003) which mitigate the impacts of the customer satisfaction index on both market-to-book ratio and cumulative excess returns. Nevertheless, the results of this study may help managers realize that satisfied customers help firms achieve better financial performance in terms of return on assets and market value.

The results of this study should be interpreted in light of three limitations. First, the customer satisfaction index is determined by the satisfaction index of a single product owned by a firm (i.e., product with the highest satisfaction index). It is possible that customer satisfaction with the firm as a whole be different from the satisfaction index for the single product. Future research might develop a more comprehensive satisfaction index for the whole firm and investigate how this overall index affects firm financial performance. However, due to time and financial constraints, we could only use the single product satisfaction index in this study.

Second, the time lag between earnings announcement, customer satisfaction survey, and publication of customer satisfaction index is relatively wide. Earnings announcement is mostly done in March, while the customer satisfaction survey is conducted in June and published in September. As indicated in Table 6, there is no more effect of earnings announcement on excess returns in September ( $p$ > 0.10 for each period). Future research might improve the measurement of unexpected earnings, most likely to use quarterly data. We find that the database for quarterly data is still not adequate to support our research due to incompleteness.

Third, the total respondents in the survey by SWA magazine/Frontier Consulting Group is limited to a maximum of 10,500 respondents in six big cities in Indonesia. Given that the total population in Indonesia is more than 200 million people, the sample might be too small to be representative of the population. Despite this limitation, the fact that the respondents are randomly selected increases the likelihood that the sample reasonably represents the characteristics of the population. Nonetheless, we recommend that for future surveys, SWA magazine/Frontier Consulting Group consider increasing the number of respondents from each city and also including respondents from other cities to increase their representations. 
Gadjah Mada International Journal of Business, September-December 2009, Vol. 11, No. 3

\section{References}

Anderson, E.W., and S. A. Mansi. 2009. Does customer satisfaction matter to investors? Findings from the bond market. Journal of Marketing Research XLVI: 703-714.

Ball, R., and P. Brown. 1968. An empirical evaluation of accounting income numbers. Journal of Accounting Research (Autumn): 159-177.

Beaver, W. H., M. L. McAnally, and C. H. Stinson. 1997. The information content of earnings and Prices: A Simultaneous equations approach. Journal of Accounting and Economics 23: 53-81.

Chand, M. 2010. The impact of HRM practices on service quality, customer satisfaction and performance in the Indian Hotel Industry. The International Journal of Human Resource Management 21 (4): 551-566.

Collins, D. W., M. Pincus and H. Xie. 1999. Equity valuation and negative earnings: The role of book value of equity. The Accounting Review 74 (1) (January): 29-61.

Cooper, R., and R. S. Kaplan. 1991. The Design of Cost Management Systems. Englewood Cliffs, N.J.: Prentice Hall.

Elitzur, R.R., and V. Yaari. 1995. Executive incentive compensation and earnings manipulation in a multi-period setting. Journal of Economic Behavior and Organization 26: 201-219.

Fisher, J. 1992. Use of non-financial performance measures. Journal of Cost Management 6 (Spring): 31-38.

Fornell, C., M. D. Johnson, E. W. Anderson, J. Cha, and B. E. Bryant. 1996. The American customer satisfaction index: Nature, purpose, and findings. Journal of Marketing 60 (October): 7-18.

Fornell, C., S. Mithas, F. V. Morgeson III, and M. S. Krishnan. 2006. Customer satisfaction and stock prices: High returns, low risk. Journal of Marketing 70 (January): 3-14.

Frank, M. Z., and V. K. Goyal. 2003. Testing the pecking order theory of capital structure. Journal of Financial Economics 67: 217-248.

Hansen, U., and T. Hennig-Thurau. 1999. National customer satisfaction indices: A critical investigation from an application perspective. Working Paper.

Hutchinson, M., and F. A. Gul. 2003. Investment opportunity set, sorporate governance practices and firm performance. Journal of Corporate Finance 182: 1-20.

Ittner, C. D., and D. F. Larcker. 1998. Are nonfinancial measures leading indicators of financial performance? An analysis of customer satisfaction. Journal of Accounting Research 36 (Supplement).

Jermias, J. 2007. The effects of corporate governance on the relationship between innovative efforts and performance. European Accounting Review 16 (4): 827-854.

Johnson, H. T. and R. S. Kaplan. 1987. Relevance Lost: The Rise and Fall or Management Accounting. Boston, MA: Harvard Business School Press.

Kaplan, R. S. and D. P. Norton. 1996. The Balanced Scorecard: Translating Strategy Into Action. Boston: Harvard Business School Press. 
Leo et al.-The Impact of Government Debt Issuance on Short-Term Interest Rates in indonesia

Kaplan, Robert S. and D. P. Norton, 2001, The Strategy-Focused Organization: How Balanced Scorecard Companies Thrive in the New Business Environment. Boston: Harvard Business School Press.

Kaplan, R. S., and D. P. Norton. 2006. Alignment: Using the Balanced Scorecard to Create Corporate Synergies. Boston: Harvard Business School Press.

Merchant, K. A., and W. A. van der Stede. 2007. Management Control Systems: Performance Measurement, Evaluation, and Incentive. New York: Prentice-Hall.

Morgeson, F., 2005. Trends in customer satisfaction with the U. S. Federal Government - findings of the ACSI. Washington, D. C.: Presentation Material (December 15).

Parker, D., and K. Hartley. 1991. Do changes in organizational status affect financial performance? Strategic Management Journal (12): 631-641.

Ramaswamy, K., 2001, Organizational ownership, competitive intensity, and firm performance: An empirical study of the Indian Manufacturing Sector. Strategic Management Journal 22: 989-998.

Simons, R., 1990. The role of management control systems in creating competitive advantage: new perspective. Accounting, Organizations and Society 15 (1): 127143.

Simons, R. 2000. Performance Measurement and Control Systems for Implementing Strategy: Text and Cases. Upper Saddle River, New Jersey: Prentice Hall.

Srivastava, R. K., T. A. Shervani, and L. Fahey. 1998. Market-based assets and shareholder value: A framework for analysis. Journal of Marketing 62 (January): 2-18.

SWA Magazine 19/XIX (September 18-October 1). 2003. Jakarta, Indonesia.

SWA Magazine 19/XXIII (September 3-12). 2007. Jakarta, Indonesia.

SWA Magazine 20/XXIV (September 18-October 8). 2008. Jakarta, Indonesia.

Teoh, S. H., and T. J. Wong. 1993. Perceived auditor quality and the earnings response coefficient. The Accounting Review 68 (April) (2): 346-366.

Tuli, K. R., and S. G. Bharadwaj. 2009. Customer satisfaction and stock return risk. Journal of Marketing 73: 184-197.

Verrecchia, R. E. 1986. Managerial discretion in the choice among financial reporting alternatives. Journal of Accounting and Economics 9: 175-196.

Vinning, A., and A. Broadman. 1992. Ownership versus competition: Efficiency in public enterprise. Public Policy 73: 205-239. 